\title{
RESPON HEMATOLOGIS IKAN KERAPU TIKUS (Cromileptes altivelis) PADA SUHU MEDIA PEMELIHARAAN YANG BERBEDA
}

\author{
Hematological response of humpback grouper fish (Cromileptes altivelis) in different \\ temperatures of media
}

Reny Lidhia Widi Samsisko ${ }^{*}$, Hari Suprapto ${ }^{2}$, and Setiawati Sigit ${ }^{1}$

${ }^{1}$ Program Studi Budidaya Perairan, Fakultas Perikanan dan Kelautan, Universitas Airlangga, Surabaya

${ }^{2}$ Departemen Manajemen Kesehatan Ikan dan Budidaya Perairan, Fakultas Perikanan dan Kelautan, Universitas Airlangga, Surabaya

* reny-1-w-09@fpk.unair.ac.id

\begin{abstract}
Abstrak
Penelitian ini bertujuan untuk mengetahui pengaruh suhu media pemeliharaan yang berbeda terhadap respon hematologis ikan kerapu tikus (Cromileptes altivelis). Metode yang digunakan dalam penelitian ini adalah metode eksperimental yang terdiri dari tiga perlakuan yaitu, Kontrol (ikan dipelihara pada suhu ruangan $30^{\circ} \mathrm{C}$ ), A (ikan dipelihara pada suhu $32^{\circ} \mathrm{C}$ ), dan B (ikan dipelihara pada suhu $34^{\circ} \mathrm{C}$ ) dengan masing-masing perlakuan diulang sebanyak tiga kali. Bahan yang digunakan dalam penelitian adalah ikan kerapu tikus (Cromileptes altivelis) yang berukuran $10-15 \mathrm{~cm}$ sebanyak 72 ekor, air laut, pellet, EDTA, aquades, larutan Hayem's, dan larutan Turk's. Ikan kerapu tikus pada perlakuan $\mathrm{A}\left(32^{\circ} \mathrm{C}\right)$ dan $\mathrm{B}\left(34^{\circ} \mathrm{C}\right)$ mengalami stres dibandingkan dengan ikan Kontrol $\left(30^{\circ} \mathrm{C}\right)$ yang ditandai dengan tingginya kadar glukosa darah hingga akhir pemeliharaan yaitu sebesar $80,7 \mathrm{mg} / \mathrm{dL}$ pada perlakuan $\mathrm{A}\left(32^{\circ} \mathrm{C}\right), 88 \mathrm{mg} / \mathrm{dL}$ pada perlakuan $\mathrm{B}\left(34^{\circ} \mathrm{C}\right)$. Nilai tertinggi total eritrosit adalah $2,86 \times 10^{6} \mathrm{sel} / \mathrm{mm}^{3}$ pada perlakuan $\mathrm{A}\left(32^{\circ} \mathrm{C}\right)$ dan $2,92 \times 10^{6} \mathrm{sel} / \mathrm{mm}^{3}$ pada perlakuan $\mathrm{B}\left(34^{\circ} \mathrm{C}\right)$; total leukosit sebesar $10,86 \times 10^{4} \mathrm{sel} / \mathrm{mm}^{3}$ pada perlakuan $\mathrm{A}\left(32^{\circ} \mathrm{C}\right)$ dan $10,93 \times 10^{4} \mathrm{sel} / \mathrm{mm}^{3}$ pada perlakuan $\mathrm{B}\left(34^{\circ} \mathrm{C}\right)$; persentase hematokrit sebesar $41,7 \%$ pada perlakuan $\mathrm{A}\left(32^{\circ} \mathrm{C}\right)$ dan $44 \%$ pada perlakuan $\mathrm{B}\left(34^{\circ} \mathrm{C}\right)$.
\end{abstract}

Kata kunci: Cromileptes altivelis, glukosa darah, eritrosit, hematokrit, leukosit

Abstract

This study aimed to determine the effect of different maintenance media temperature on haematological response of humpback grouper (Cromileptes altivelis). The method used in this study is an experimental method that consists of three treatments, namely Kontrol (fish kept at room temperature $30^{\circ} \mathrm{C}$ ), A (fish maintained at a temperature of $32^{\circ} \mathrm{C}$ ), and $\mathrm{B}$ (fish maintained at a temperature of $34^{\circ} \mathrm{C}$ ) with each treatment was repeated three times. Materials used in the study is the humpback grouper (Cromileptes altivelis) measuring $10-15 \mathrm{~cm}$ by 72 tails, sea water, pellets, EDTA, aquadest, Hayem's solution, and Turk's solution. Humpback grouper on treatment A $\left(32^{\circ} \mathrm{C}\right)$ and $\mathrm{B}\left(34^{\circ} \mathrm{C}\right)$ to stress than the control fish $\left(30^{\circ} \mathrm{C}\right)$ which is characterized by high blood glucose levels by the end of maintenance in the amount of $80.7 \mathrm{mg} / \mathrm{dL}$ on treatment $\mathrm{A}\left(32^{\circ} \mathrm{C}\right), 88 \mathrm{mg} / \mathrm{dL}$ on treatment $\mathrm{B}\left(34^{\circ} \mathrm{C}\right)$. Highest value of total erythrocytes was $2.86 \times 10^{6}$ cells $/ \mathrm{mm}^{3}$ in treatment $\mathrm{A}\left(32^{\circ} \mathrm{C}\right)$ and $2,92 \times 10^{6} \mathrm{cells} / \mathrm{mm}^{3}$ in treatment $B\left(34^{\circ} \mathrm{C}\right)$, total leukocytes of $10.86 \times 10^{4}$ cells $/ \mathrm{mm}^{3}$ in treatment $\mathrm{A}\left(32^{\circ} \mathrm{C}\right)$ and $10.93 \times 10^{4} \mathrm{cells} / \mathrm{mm}^{3}$ in treatment $\mathrm{B}\left(34^{\circ} \mathrm{C}\right)$; percentage hematocrit of $41.7 \%$ in treatment $\mathrm{A}\left(32^{\circ} \mathrm{C}\right)$ and $44 \%$ in treatment $\mathrm{B}\left(34^{\circ} \mathrm{C}\right)$.

Keywords: Cromileptes altivelis, blood glucose, erythocytes, hematocrit, leukocytes

\section{PENDAHULUAN}

Salah satu jenis ikan laut yang memiliki nilai ekonomis penting adalah ikan kerapu tikus (Cromileptes altivelis) (Suburhan dkk., 2005). Ikan kerapu tikus merupakan salah satu jenis ikan karang yang dalam dunia internasional dikenal dengan nama humpback groupers atau coral reef fishes yang sudah dapat dibudidayakan di keramba jaring apung.
Selain itu, ikan kerapu tikus juga merupakan salah satu komoditas unggulan ekspor hasil perikanan dengan potensi pengembangan yang masih cukup besar. Besarnya permintaan dan tingginya harga jual ikan kerapu menjadi alasan utama pengembangan usaha budidaya kerapu (Azhar, 2011).

Salah satu permasalahan yang dihadapi dalam budidaya ikan kerapu tikus

Diterima/submitted:4 Januari 2014

Disetujui/accepted:24 Januari 2014 
adalah angka kelulushidupan yang rendah. Rendahnya nilai kelulushidupan disebabkan karena ikan kerapu tikus mudah mengalami stres. Perubahan suhu di lingkungan media pemeliharaan dapat mempengaruhi kehidupan ikan bahkan dapat menyebabkan stres. Suhu yang tinggi dapat menyebabkan dissolved oxygen menurun dan mengurangi selera makan ikan (Kelabora, 2010).

Meskipun ikan dapat beraklimatisasi pada suhu yang relatif tinggi, tetapi pada suatu derajat tertentu kenaikan suhu dapat menyebabkan kematian ikan. Perubahan drastis suhu sampai mencapai $5^{\circ} \mathrm{C}$ dapat menyebabkan stres pada ikan atau membunuhnya (Cholik dkk., 1986). Kubilay and Ulukoy (2002) menyatakan bahwa stres adalah ketidak mampuan suatu organisme mempertahankan kondisi homeostasis akibat terganggunya individu tersebut oleh adanya rangsangan dari luar yang dinamai dengan stressor.

\section{METODOLOGI}

\section{Metode Penelitian}

Metode yang digunakan dalam penelitian ini adalah metode eksperimental yang terdiri dari tiga perlakuan yaitu, Kontrol (K), A, dan B dengan masingmasing perlakuan diulang sebanyak tiga kali kemudian data yang diperoleh disajikan secara deskriptif. Ikan kerapu tikus pada Kontrol (K) dipelihara pada suhu ruangan $\left(30^{\circ} \mathrm{C}\right)$, pada perlakuan $\mathrm{A}$ ikan kerapu tikus dipelihara pada suhu $32^{\circ} \mathrm{C}$, dan pada perlakuan $\mathrm{B}$ ikan kerapu tikus dipelihara pada suhu $34^{\circ} \mathrm{C}$. Pemeliharaan ikan kerapu tikus pada penelitian ini dilakukan selama 15 hari.

\section{Persiapan Akuarium dan Ikan Sampel}

Akuarium yang akan dipergunakan dalam penelitian ini dicuci terlebih dahulu, setelah bersih kemudian akuarium berukuran $45 \times 45 \times 45 \mathrm{~cm}$ diisi dengan menggunakan air laut hingga $3 / 4$ bagian, yaitu $68 \mathrm{~L}$. Akuarium diberi aerasi dan diisi ikan kerapu tikus. Ikan kerapu tikus yang akan digunakan dalam penelitian ini diseleksi terlebih dahulu. Ukuran panjang ikan yang digunakan yaitu $10-15 \mathrm{~cm}$.

\section{Pengambilan Darah}

Pada pengambilan darah, ikan diletakkan dengan kepala disebelah kiri, sebelumnya spuit sudah dibilas dengan EDTA $10 \%$ sebagai antikoagulan. Sampel darah diambil menggunakan teknik punctie cardiac yaitu pengambilan darah tepat pada bagian jantung ikan menggunakan spuit 1 ml. Darah yang telah diambil, dimasukkan ke dalam tabung eppendorf untuk segera diamati gambaran darahnya.

\section{Pengukuran Kadar Glukosa Darah}

Pengukuran glukosa darah pada ikan kerapu tikus menggunakan alat Glucossure Star. Untuk pengukuran menggunakan alat Glucosure Star, sampel darah ikan yang didapat kemudian diteteskan pada test strip glucose, kemudian test strip dimasukkan pada glucose meter sehingga terbaca hasil glukosa darah yang terkandung.

\section{Pengukuran Total Eritrosit}

Darah dihisap dengan pipet yang berisi bulir pengaduk warna merah sampai skala 0,5. Lalu ditambahkan larutan Hayem's (berfungsi untuk mematikan selsel darah putih) sampai skala 101. Pengadukan darah di dalam pipet dilakukan dengan mengayunkan tangan selama 3 - 5 menit sehingga darah tercampur rata. Setelah itu tetesan pertama larutan darah dalam pipet dibuang, selanjutnya teteskan pada haemacytometer tipe Neubauer kemudian ditutup dengan cover glass bagian yang berlekuk. Rumus untuk menghitung eritrosit adalah sebagai berikut (Nabib dan Pasaribu, 1989):

Keterangan :

$$
\Sigma \text { Eritrosit }=\frac{\mathrm{A}}{\mathrm{N}} \times \frac{1}{\mathrm{~V}} \times \mathrm{Fp}
$$

A : $\Sigma$ sel terhitung

$\mathrm{V}$ : Volume kotak Haemocytometer

$\mathrm{N}: \Sigma$ kotak Haemocytometer yang diamati

Fp : Faktor Pengenceran 


\section{Pengukuran Total Leukosit}

Sampel darah ikan kerapu tikus diambil dengan menggunakan spuit $1 \mathrm{cc}$, sebanyak $\pm 1 \mathrm{ml}$. Sampel kemudian diencerkan dengan menggunakan larutan Turk's, campur darah secara perlahan agar tidak merusak sel darah. Mengambil darah dengan menggunakan pipet dan letakkan ujung pipet pada Neubauer. Lalu meletakkan coverglass diatas petak hitung Neubauer, kemudian diamati menggunakan mikroskop dengan perbesaran 1000 kali. Penghitungan jumlah leukosit hanya pada empat bidang besar, dimulai dari sudut sebelah kiri atas, lalu kekanan, kemudian turun kebawah dan dari kanan kemudian kekiri (Blaxhall and Daisley, 1973).

Jumlah sel darah putih menggunakan rumus sebagai berikut :

$$
\Sigma \text { Leukosit }=\frac{\Sigma \text { sel }}{\text { vol. kotak besar }} \times \mathrm{Fp}
$$

\section{Pengukuran Kadar Hematokrit}

Sampel darah ikan kerapu tikus diambil dengan menggunakan spuit $1 \mathrm{cc}$ sebanyak $\pm 1 \mathrm{ml}$. Pengambilan darah melalui vena caudalis. Sampel darah kemudian dimasukkan ke dalam tabung mikrohematokrit hingga mencapai $3 / 4$ bagian, lalu disumbat pada bagian ujung dengan menggunakan kretoseal. Sampel darah tersebut di centrifuge dengan kecepatan $6.000 \mathrm{rpm}$ selama 5 menit. Pengukuran kadar hematokrit dilakukan dengan menggunakan microhematocrit reader (Anderson and Siwicki, 1993).

\section{HASIL DAN PEMBAHASAN}

Hasil dari penelitian ini adalah data pengukuran kadar glukosa darah, total eritrosit, persentase hematokrit, dan total leukosit. Hasil tersebut digunakan untuk mengetahui pengaruh suhu media pemeliharaan yang berbeda terhadap respon hematologis ikan kerapu tikus (Cromileptes altivelis). Parameter kualitas air berupa data rata-rata $\mathrm{DO}, \mathrm{pH}$, dan salinitas selama penelitian berlangsung ditampilkan sebagai data pendukung.

Hasil pengukuran kadar glukosa darah ikan kerapu tikus yang dipelihara pada suhu yang berbeda mengalami peningkatan. Kadar glukosa darah ikan yang dipelihara pada suhu $32^{\circ} \mathrm{C}$ dan $34^{\circ} \mathrm{C}$ lebih tinggi dibandingkan ikan yang dipelihara pada suhu ruangan (kontrol). Peningkatan kadar glukosa darah ikan uji pada perlakuan A $\left(32^{\circ} \mathrm{C}\right)$ hingga hari ke-15 mencapai $80,7 \mathrm{mg} / \mathrm{dL}$ begitu juga dengan ikan uji pada perlakuan $\mathrm{B}\left(34^{\circ} \mathrm{C}\right)$ yang kadar glukosa darahnya mencapai 88 $\mathrm{mg} / \mathrm{dL}$.

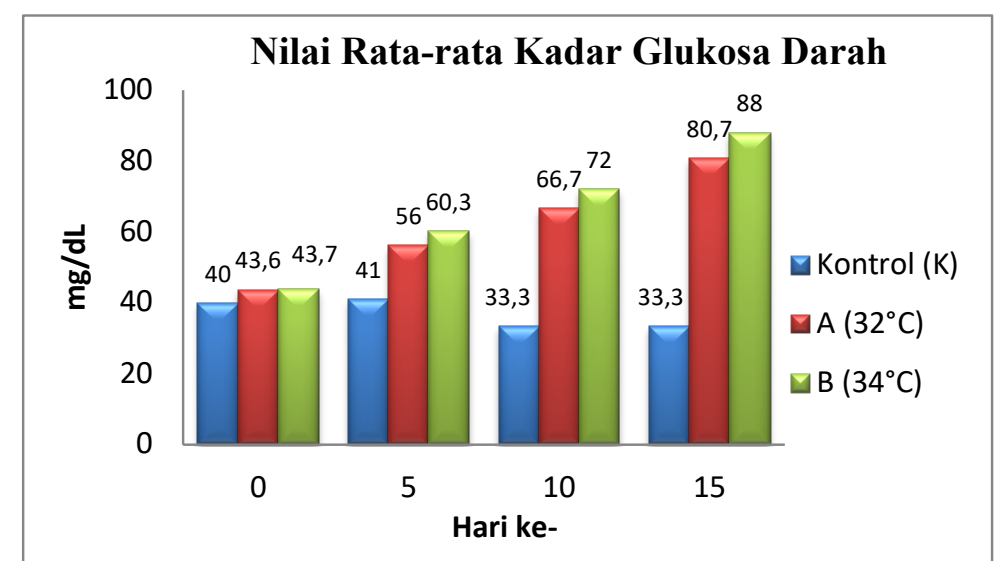

Gambar 1. Diagram hasil pengukuran kadar rata-rata glukosa darah ikan kerapu tikus pada hari ke- $0,5,10$, dan 15 
Hasil pengukuran eritrosit ikan kerapu tikus perlakuan $\mathrm{A}\left(32^{\circ} \mathrm{C}\right)$ dan $\mathrm{B}$ $\left(34^{\circ} \mathrm{C}\right)$ mengalami peningkatan pada hari ke-5 hingga ke-10 kemudian mengalami penurunan kembali pada hari ke-15. Nilai eritrosit tertinggi diperoleh dari perlakuan
B $\left(34^{\circ} \mathrm{C}\right)$ sebesar $2,92 \times 10^{6} \mathrm{sel} / \mathrm{mm}^{3}$. Nilai rata-rata eritrosit dari perlakuan $\mathrm{A}\left(32^{\circ} \mathrm{C}\right)$ dan $\mathrm{B}\left(34^{\circ} \mathrm{C}\right)$ pada pengamatan hari ke-15 mendekati nilai eritrosit ikan sebelum diberikan perlakuan.

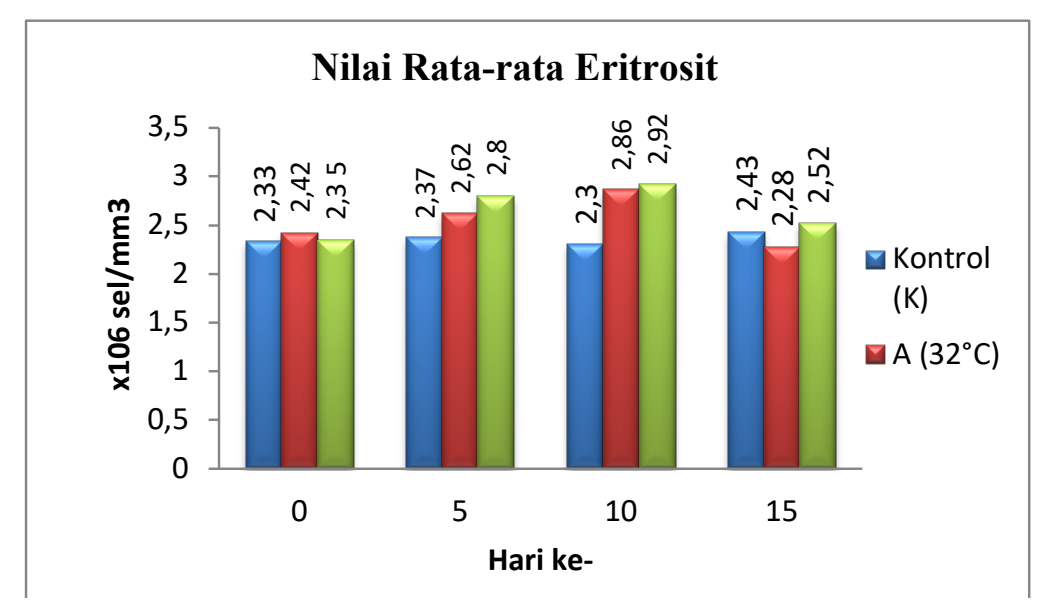

Gambar 2. Diagram hasil pengukuran nilai rata-rata total eritrosit ikan kerapu tikus pada hari ke- $0,5,10$, dan 15

Pada hasil pengukuran hematokrit ikan kerapu tikus pada hari ke-0, 5, 10, dan 15 terlihat bahwa terjadi peningkatan kadar hematokrit ikan perlakuan $\mathrm{A}\left(32^{\circ} \mathrm{C}\right)$ dan $\mathrm{B}$ $\left(34^{\circ} \mathrm{C}\right)$ pada pengamatan hari ke-5 dan ke10. Pada hari ke-15 kadar hematokrit ikan kerapu tikus perlakuan $\mathrm{A}\left(32^{\circ} \mathrm{C}\right)$ dan $\mathrm{B}$ $\left(34^{\circ} \mathrm{C}\right)$ mengalami penurunan mendekati kadar hematokrit pada hari ke-0. Kadar hematokrit tertinggi terlihat pada ikan uji perlakuan B $\left(34^{\circ} \mathrm{C}\right)$ yaitu sebesar $44 \%$.

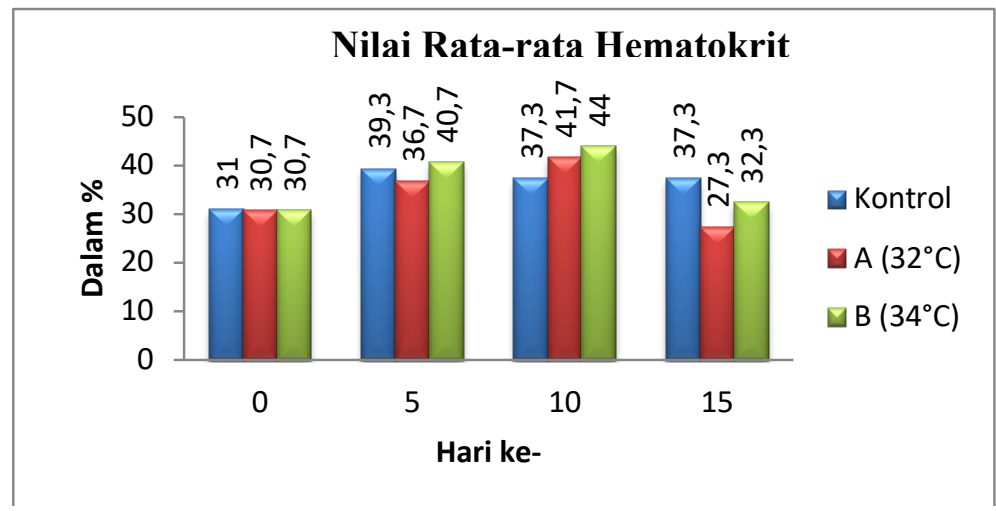

Gambar 3. Diagram hasil pengukuran nilai rata-rata hematokrit ikan kerapu tikus pada hari ke- $0,5,10$, dan 15

Hasil pengukuran leukosit ikan kerapu tikus pada perlakuan $\mathrm{A}\left(32^{\circ} \mathrm{C}\right)$ dan $\mathrm{B}\left(34^{\circ} \mathrm{C}\right)$ selama pemeliharaan mengalami peningkatan dibandingkan dengan Kontrol
(K). Jumlah total leukosit tertinggi diperoleh dari ikan perlakuan $\mathrm{B}\left(34^{\circ} \mathrm{C}\right)$ pada pengamatan hari ke-15 yaitu sebesar $10,93 \times 10^{4} \mathrm{sel} / \mathrm{mm}^{3}$. 


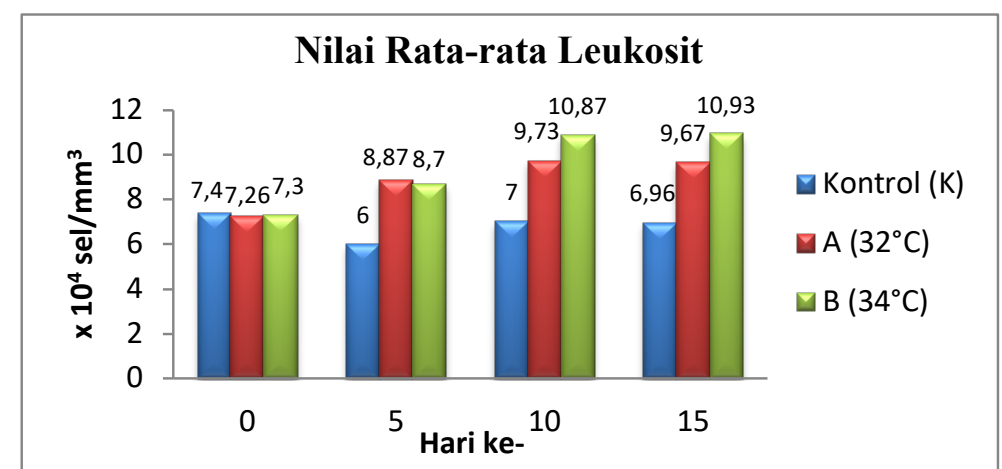

Gambar 4. Diagram hasil pengukuran nilai rata-rata leukosit ikan kerapu tikus pada hari ke-0, 5,10 , dan 15

\section{Kualitas Air}

Tabel 1. Data rata-rata kualitas air selama penelitian

\begin{tabular}{ccccc}
\hline Perlakuan & Suhu $\left({ }^{\circ} \mathrm{C}\right)$ & Salinitas $(\mathrm{ppt})$ & DO $(\mathrm{ppm})$ & $\mathrm{pH}$ \\
\hline K (kontrol) 1 & 30 & 34 & 7,26 & 8,13 \\
K (kontrol) 2 & 30 & 34 & 6,3 & 8,14 \\
K (kontrol) 3 & 30 & 34 & 6,26 & 8,14 \\
A1 & 32 & 34 & 6 & 8,15 \\
A2 & 32 & 34 & 6,2 & 8,16 \\
A3 & 32 & 34 & 5,9 & 8,14 \\
B1 & 34 & 34 & 4,9 & 8,17 \\
B2 & 34 & 34 & 4,87 & 8,16 \\
B3 & 34 & 34 & 4,85 & 8,16 \\
\hline
\end{tabular}

Data pengukuran kualitas air pada perlakuan Kontrol $\left(30^{\circ} \mathrm{C}\right)$ menunjukkan kisaran $\mathrm{pH}$ yaitu $8,13-8,14$, untuk oksigen terlarut yaitu $6,26-7,26 \mathrm{mg} / \mathrm{l}$, dan salinitas 34 ppt. Hasil pengukuran kualitas air pada perlakuan Kontrol (K) menunjukkan bahwa kondisi kualitas air pada akuarium dalam kondisi normal, artinya kondisi kualitas air tersebut sesuai dan berada pada kisaran normal bagi kelangsungan hidup ikan kerapu tikus. Kualitas air pada perlakuan A $\left(32^{\circ} \mathrm{C}\right)$ menunjukkan kisaran $\mathrm{pH} 8,14-8,16$, oksigen terlarut 5,9-6,2 mg/dl, dan salinitas 34 ppt. Kualitas air pada perlakuan B $\left(34^{\circ} \mathrm{C}\right)$ menunjukkan kisaran $\mathrm{pH} 8,12-8,16$, oksigen terlarut 4,85-4,9 mg/l, dan salinitas sebesar 34 ppt.

Suhu merupakan salah satu faktor lingkungan yang dapat menimbulkan stres pada ikan. Perubahan suhu yang cukup besar dan mendadak dapat menimbulkan stres pada ikan. Stres adalah ketidak mampuan suatu organisme mempertahan- kan kondisi homeostasis akibat terganggunya individu tersebut oleh adanya rangsangan dari luar yang dinamai dengan stressor (Kubilay and Ulukoy, 2002).

Hematologi sering juga digunakan untuk mendeteksi perubahan fisiologis yang disebabkan oleh stres lingkungan dan juga berhubungan dengan status kesehatan ikan, parameter yang biasa menjadi indeks dalam menentukan status kesehatan ikan adalah total sel darah merah, sel darah putih, hemoglobin, hematokrit, sedangkan untuk melihat tingkat stres biasanya juga diukur kadar kortisol dan glukosa darah (Al-Attar 2005).

Ikan kerapu memiliki kadar glukosa normal yang berkisar antara 28,8-34,2 $\mathrm{mg} / \mathrm{dL}$ (Porchas et al., 2009). Salah satu indikasi ikan stres adalah meningkatnya kadar glukosa dalam plasma. Adanya respons stres, akan merangsang hipothalamus untuk melepaskan corticotrophin releasing factor (CRF), dan $\mathrm{CRF}$ ini

Diterima/submitted:4 Januari 2014 Disetujui/accepted:24 Januari 2014 
akan merangsang kelenjar hipofisa anterior untuk melepaskan hormon adrenocorticotropin hormone (ACTH). Kemudian ACTH akan merangsang sel-sel interrenal (medulla adrenal) untuk menghasilkan kortisol dan hormon katekolamin, seperti epinefrin (Wedemeyer, 1996). Hormonhormon ini berperan dalam proses glukoneogenesis yang akan mendeposisi cadangan glikogen di hati dan otot untuk meningkatkan kadar glukosa darah (Hastuti, 2004).

Untuk mengukur tingkat stres pada ikan dapat dilakukan dengan melakukan pengamatan terhadap gambaran darah yaitu dengan mengamati kadar haemoglobin, jumlah sel darah merah, sel darah putih. Hal ini didasarkan kenyataan bahwa stres yang memicu sekresi kortisol akan mempengaruhi gambaran darah Gbore et al. (2006). Peningkatan sel darah merah merupakan usaha homeostasis tubuh ikan dalam upaya untuk memperbanyak hemoglobin guna mengikat oksigen. Ikan yang hidup di air rendah oksigen akan mengalami hematopoiesis sehingga eritrositnya meningkat sebagai upaya penyesuaian penambahan oksigen (Setiawati, 2007).

Tingginya jumlah eritrosit dalam darah ikan diduga karena ikan dalam keadaan stres (Mones, 2008). Menurut Affandi dan Tang (2002), stres bisa disebabkan oleh kondisi lingkungan yang buruk dan tidak nyaman lagi bagi kehidupan ikan, salah satunya adalah kondisi oksigen perairan yang kurang. Menurunnya jumlah eritrosit ikan kerapu tikus pada hari ke-15 diduga karena ikan mulai berdaptasi dengan suhu media pemeliharaan.

Perubahan nilai parameter hematologis berkaitan dengan peningkatan penyebab stres (stressor) (Gabriel et al., 2007). Nilai hematokrit adalah suatu istilah yang digunakan untuk menyatakan persentase (berdasarkan volume) dari darah yang terdiri atas sel-sel darah merah. Terjadinya peningkatan kadar hematokrit ikan kerapu tikus perlakuan $\mathrm{A}\left(32^{\circ} \mathrm{C}\right)$ dan $\mathrm{B}\left(34^{\circ} \mathrm{C}\right)$ diduga karena ikan uji mengalami stres dan beradaptasi dengan perlakuan yang diberi- kan seperti suhu. Pada keadaan hipoksia akan menyebabkan sel membengkak sehingga meningkatkan nilai hematokrit (Mones, 2008).

Penghitungan total leukosit penting dilakukan untuk mengetahui status kesehatan ikan. Kortisol juga berhubungan erat dengan sistem imun, kortisol berfungsi menekan sistem imun sehingga menyebabkan menurunnya jumlah total leukosit. Pada stres ringan yang masih dapat diatasi oleh tubuh ikan, akan terjadi peningkatan jumlah total leukosit, dimana proses tersebut merupakan upaya untuk mengatasi stres yang ditimbulkan oleh stressor (Harper and Wolf, 2009).

Tingginya jumlah leukosit disebabkan oleh tingkat stres pada ikan akibat memburuknya kualitas air (Paulo et al., 2009). Terjadinya peningkatan jumlah leukosit atau disebut dengan leukositosis merupakan reaksi "ephinephrine" dimana neutrofil dan limfosit dimobilisasi ke dalam sirkulasi umum sehingga menaikkan jumlah total leukosit (Aliambar, 1999).

\section{KESIMPULAN DAN SARAN Kesimpulan}

Ikan kerapu tikus pada perlakuan A $\left(32^{\circ} \mathrm{C}\right)$ dan $\mathrm{B}\left(34^{\circ} \mathrm{C}\right)$ mengalami stres dibandingkan dengan ikan Kontrol $\left(30^{\circ} \mathrm{C}\right)$. Hal tersebut ditandai dengan tingginya kadar glukosa darah hingga akhir pemeliharaan yaitu sebesar $80,7 \mathrm{mg} / \mathrm{dL}$ pada perlakuan A $\left(32^{\circ} \mathrm{C}\right), 88 \mathrm{mg} / \mathrm{dL}$ pada perlakuan $\mathrm{B}\left(34^{\circ} \mathrm{C}\right)$.

Parameter hematologis seperti total eritrosit, total leukosit, dan hematokrit yang mengalami peningkatan juga menandakan bahwa ikan kerapu tikus yang dipelihara pada suhu $32^{\circ} \mathrm{C}$ dan $34^{\circ} \mathrm{C}$ mengalami stres dibandingkan ikan Kontrol $\left(30^{\circ} \mathrm{C}\right)$. Nilai tertinggi total eritrosit adalah $2,86 \times 10^{6}$ $\mathrm{sel} / \mathrm{mm}^{3}$ pada perlakuan A $\left(32^{\circ} \mathrm{C}\right)$ dan $2,92 \times 10^{6} \mathrm{sel} / \mathrm{mm}^{3}$ pada perlakuan $\mathrm{B}\left(34^{\circ} \mathrm{C}\right)$; total leukosit sebesar $10,86 \times 10^{4} \mathrm{sel} / \mathrm{mm}^{3}$ pada perlakuan A $\left(32^{\circ} \mathrm{C}\right)$ dan $10,93 \times 10^{4}$ $\mathrm{sel} / \mathrm{mm}^{3}$ pada perlakuan $\mathrm{B}\left(34^{\circ} \mathrm{C}\right)$; persentase hematokrit sebesar $41,7 \%$ pada 
perlakuan $\mathrm{A}\left(32^{\circ} \mathrm{C}\right)$ dan $44 \%$ pada perlakuan B $\left(34^{\circ} \mathrm{C}\right)$.

\section{Saran}

Perlu adanya penelitian lebih lanjut mengenai pengaruh dari suhu terhadap faktor lain dari ikan kerapu.

\section{DAFTAR PUSTAKA}

Affandi, R. dan U.M. Tang. 2002. Fisiologi Hewan Air. Riau: Uni press.

Al-Attar, A. M. 2005. Changes in Haematological Parameters of The Fish Oreochromis niloticus Treated With Sublethal Concentration of Cadmium. Pakistan Journal of Biological Sciences 8(3) : 421 424.

Aliambar, S.H. 1999. Pengaruh Pengendalian Hewan terhadap Temperatur, Nadi dan Respirasi Nilai Hematologi dan Kimia Darah Rusa (Curvus termorensi, Blainville 1822). Institut Pertanian Bogor.

Anderson, D. P. dan A. K. Siwicki. 1993. Injection or Immersion Delivery of Selected Immunostimulant to Trout Demonstrate Enhancement of Non Specific Defence Mechannism and Protective Immunity. In: Sharriff, M. J., R. Arthur, R. P. Subasinghe (Eds.). Discasc in Asian Aquaculture II. Fish Health Section Asian Society. pp. 413-426.

Blaxhall and K. W. Deasley. 1973. Dasley : Routine Haematological Methods for Use With Fish Blood. Journal of Fish Biology. pp. 577-581.

Gabriel UU, Amakiriand EU, Ezeri GNO. 2007. Haematology and gill pathology of Clarias gariepinus exposed to refined petroleum oil, kerosene under laboratory conditions. Journal of Animal and Veterinary Advances 6(3): 461-465.

Gbore, F. A., Oginni. O, Adewole A. M, Aladetan J. O. 2006. The Effect Of Transportation and Handling Stress on Haematology and Plasma Biochemistry in Fingerlings of
Clarias gariepinus and Tilapia zilii. Word Journal of Agriculture Sciences 2(2): 208-212.

Harper, C. and J. C. Wolf. 2009. Morphologic Effects of The Stress Response in Fish.

Hastuti, S. 2004. Respon Fisiologis Ikan Gurami (Osphronemus gouramy, Lac.) yang Diberi Pakan Mengandung Kromium-Ragi Terhadap Penurunan Suhu Lingkungan. Disertasi. Sekolah Pascasarjana. Institut Pertanian Bogor. Bogor. hal. 6-36.

Kubilay. A and G. Ulukoy. 2002. The Effects of Acute Stress on Rainbow Trout (Oncorhynchus mykiss). Turkish Journal of Zooloogy, 26: 249-254.

Mones, R. A. 2008. Gambaran Darah Pada Ikan Mas (Cyprinus carpio Linn) Strain Majalaya Yang Berasal Dari Daerah Ciampea Bogor. Skripsi. Fakultas Kedokteran Hewan. Institut Pertanian Bogor. Bogor. 35 hal.

Nabib, R. dan F. H. Pasaribu. 1989. Patologi dan Penyakit Ikan. Departemen Pendidikan dan Kebudayaan. Direktorat Jenderal Pendidikan Tinggi. Pusat Antar Universitas Bioteknologi. Institut Pertanian Bogor. UPT Produksi MediaInformasi LSI-IPB. Bogor.

Paulo, C. F. C., Pedro H. S. K., Elaine A., Correia S., and Bernardo B. 2009. Transport of Jundia Rhamdia quelen Juveniles at Different Loading Densities: Water Quality and Blood Parameters. Journal. Neotropical Ichthyology, 7(2) : 283-288.

Porchas, M. M., L. R. M. Cordova and R. R Enriquez. 2009. Cortisol and glucosa: Reliable Indicators of Fish Stress. Pan-American Journal of Aquatic Sciences, 4(2):158-178.

Setiawati, M., T. I. Winarno, M. A. Suprayudi, I. Mokoginta, W. Manalu. 2007. Mineral Besi Sebagai Peningkat Vitalitas Ikan

Diterima/submitted:4 Januari 2014 Disetujui/accepted:24 Januari 2014 
Journal of Aquaculture and Fish Health Vol. 3 No.1

Kerapu Bebek (Cromileptes altivelis) Saat Kondisi Stres Hipoksia. Jurnal Ilmu Pertanian Indonesia, 12 (1) : 8-14.

Wedemeyer, G. A. 1996. Physiology of fish in intensive culture system. Chapman and Hall. 115 Fifth Avenue New York. 